\title{
BIAYA OPERASI \\ SEKOLAH MENENGAH KEJURUAN NEGERI KATEGORI SBI/RSBI DI DIY
}

\author{
Moch Alip \\ Fakultas Teknik Universitas Negeri Yogyakarta \\ moch_alip@uny.ac.id
}

\begin{abstract}
Abstrak
Penelitian bertujuan mengungkap besar biaya operasi (BO) dan dana operasi nonpersonalia dalam penyusunan anggaran Sekolah Menengah Kejuruan Bertaraf Internasioanl (SMK-BI) di Daerah Istimewa Yogyakarta (DIY). Penelitian evaluatif populatif ini menggunakan model discrepancy dengan pendekatan penghitungan biaya berbasis kegiatan (activity based costing, disingkat $\mathrm{ABC}$ ). Data dikumpulkan melalui wawancara dan kaji dokumen kemudian dianalisis secara kualitatif dan kuantitatif. Hasil menunjukkan bahwa pengelola belum pernah menghitung besar BO nonpersonalia per Program Keahlian (PK) sehingga anggaran disusun per sekolah dan tidak mengakomodasi perbedaan kebutuhan bahan dan alat habis pakai (BAHP) antar PK. Besar BO nonpersonalia SMK-BI di DIY hampir sama dengan standar biaya SMK SSN, yaitu Rp2.166.237,00 untuk kelompok bidang non-teknik dan sebesar Rp2.287.066,00 untuk kelompok bidang teknik. Dana operasi nonpersonalia dari Pemerintah sekitar $10 \%$ s.d. $16 \%$ dari kebutuhan sehingga tidak cukup untuk pengadaan BAHP sekitar $10,5 \%$ s.d. $19,4 \%$ (idealnya $10 \%$ s.d. $30 \%$ ) sehingga yang ditanggung orang tua siswa sebesar $84 \%$ s.d. $90 \%$. Pemerintah perlu mengalokasikan dana operasi program peningkatan mutu sekolah seperti SMK-BI sesuai kebutuhan dan mendorong penerapan anggaran berbasis kinerja.
\end{abstract}

Kata kunci: biaya operasi SMK

\section{OPERATIONAL COST OF STATE VOCATIONAL HIGH SCHOOLS IN SBI/RSBI CATEGORY IN DIY}

\author{
Moch Alip \\ Fakultas Teknik Universitas Negeri Yogyakarta \\ moch_alip@uny.ac.id
}

\begin{abstract}
The objectives of this research are to reveal nonpersonel operational cost and funding in compossing the budget of world class of vocational school in Yogyakarta Special Province. The evaluatif populatif research used a discrepancy model and an activity based costing approach. Data were collected through interview and document analysis and analyzed by qualitatif and quantitatif tecnique. The result showed that the management had not calculated nonpersonel operational cost of each study program, so the school budget did not acommodate the difference cost of consumabel material between study programmes. Based on the budget documents, the nonpersonel operational cost per student per year is Rp2.166.237,00 for non-technical programes and Rp2.287.066,00 for technical programes. The cost was not much higher than that for standar schools. The fund from goverment is varies from $10 \%$ up to $16 \%$. It is not enough for consumable materials of workshop activities that up to $10,5 \%$ for non-technical programes and $19,4 \%$ for technical programes. The small fund from goverment made the parent have to pay $84 \%$ up to $90 \%$ of nonpersonel operational cost, which is too expensive for poor families. The goverment should alocate appropriate fund when launching special programes for improving quality of education and implement performance based budgeting.
\end{abstract}

Keywords: operational cost of vocational high school 


\section{Pendahuluan}

Peningkatan mutu pendidikan termasuk sekolah menengah kejuruan (SMK) merupakan amanat Undang-Undang Republik Indonesia No. 20 Tahun 2003 (UU No 20 Th 2003) tentang Sistem Pendidikan Nasional (Sisdiknas). Salah satu tindak lanjutnya adalah penyelenggaraan rintisan sekolah bertaraf internasional (RSBI) atau sekolah bertaraf internasional (SBI) berlandaskan Peraturan Pemerintah Republik Indonesia Nomor 19 Tahun 2005 tentang Standar Nasional Pendidikan (PP 19 Th. 2005). Program tersebut menimbulkan pro dan kontra. Pembantu Rektor I UNS (Suara Karya, 27 Mei 2010) menyatakan bahwa pemberian label SBI atau RSBI memang diperlukan sebagai upaya peningkatan mutu supaya lulusan dapat bersaing dengan lulusan dari negara lain tetapi Pemerintah harus ketat dalam menerapkan standar karena biaya mahal tidak menjamin mutu. Namun, Walikota Solo kurang setuju terhadap program tersebut karena biayanya dinilai mahal (Solo Pos 31 Januari 2010). Di sisi lain, pihak sekolah menyatakan bahwa penyelenggaraan SMK bertaraf internasional (SMK-BI) belum diikuti dengan pendanaan yang memadai. Brock, Marshall, dan Tucker (Washington Post, 2009) mengemukakan 10 langkah menuju World-Class Schools, antara lain: pengelolaan yang akuntabel dan penyediaan dana dari pemerintah bagi anak keluarga miskin.

Amat Jaedun (2010) melaporkan bahwa penyelenggaraan SMK RSBI di DIY menghadapi kendala terbatasnya dana, namun belum ada informasi berapa yang dibutuhkan, berapa dana tersedia dari pemerintah khususnya bagi anak miskin, dan berapa yang harus ditanggung masyarakat/ orang tua peserta didik. Pemerintah sudah menetapkan besar biaya operasi (BO) untuk sekolah standar nasional (SSN), namun BO untuk SBI belum. Oleh karena itu perlu penelitian untuk memperoleh informasi tentang berapa besar biaya dan dana operasi SMKBI di DIY sebagai bahan penyusunan kebijakan pemerintah tentang penyediaan dana penyelenggaraan program peningkatan mutu sekolah.
Pendidikan kejuruan merupakan bagian penting dari sistem pendidikan di Austria, German, Liechtenstein, dan Swiss, seperti dikemukakan Shapiro and Purpel (2003) sebagai berikut: "Vocational education is an important part of the education systems in Austria, Germany, Liechtenstein and Switzerland ...”. Rauner dan Maclean (2008) menyatakan bahwa "Vocational education is considered a key factor for improving or maintaining the competitiveness of enterprises and national economies". Lerman (dalam Rauner dan Maclean) menyatakan bahwa:

"Broader benefit of Vocational Education and Training (VET) for individual and communities. ... VET raises self-esteem, self confidence, social skills, social contacs, and motivation to learn, and clarifies future career prospects. These effects, in turn, improve physical health and reduce depression, teenage pregnancy, and criminal activity."

Pendidikan kejuruan selain menyumbang peningkatan daya saing usaha dan ekonomi nasional suatu negara dan masyarakat juga meningkatkan kondisi sosial dan psikologis individu peserta didik seperti selfesteem, ketrampilan sosial, dan motivasi belajar demi masa depannya, dan selanjutnya menurunkan tingkat depresi, angka kehamilan remaja, dan kriminalitas.

Swiss Agency for Development and Cooperation (SDC) (2005), State Departments of Education of USA (2002), dan Gasskov (2000) mengemukakan konsep senada bahwa pendidikan dan pelatihan (diklat) kejuruan adalah diklat untuk bekerja di industri dan meningkatkan produktivitas personal dan sosial, namun pendanaannya memerlukan campur tangan pemerintah untuk memastikan pemerataan layanan sesuai dengan kebutuhan per jenis program dan kondisi sosial ekonomi peserta didik. Dengan demikian diklat kejuruan tetap diperlukan walaupun memerlukan biaya lebih besar (Onstenk dalam Rauner and Maclean, 2008) walaupun ada yang kurang setuju karena nilai balik diklat kejuruan (rate of ret urn) relatif sama dengan sekolah umum (Psacharopoulos, 1985; Tilak dalam Keeves dan Watanabe, 2002; Hoeckel, 2008). 
Chalker dan Haynes (1995) menyatakan bahwa World-Class Schools merupakan upaya peningkatan mutu pendidikan melalui penerapan standar baru yang mencakup: pendanaan, waktu belajar, jumlah siswa per rombongan belajar (class size), persiapan, kurikulum, system penilaian, tatakelola, dan budaya mutu. Program peningkatan mutu SMK melalui program SMK-BI atau sejenisnya juga dilakukan Singapura karena tuntutan global dan sebagai modal pengembangan ekonomi, seperti dilaporkan Law Song Seng (2007) sebagai berikut:

"Vocational technical education (VTE) system play a crucial role in the social and economic development of a nation. Owing to their nature, they are continuously subject to the forces driving change in the school, industry, society. ... the modern histori of VTE, bighlights the transformation of the Imstitute of Technical Education (ITE) as a world class post secondary institution in Singapore"

Stewart (2010) menyampaikan pendapat sejenis sebagai berikut: "Singapore has developed a close linkage between education and economic development, studying where they want the economy to grow and then educating a rising workforce to be prepared accordingly".

Di Germany, dana penyelenggaraan sekolah kejuruan menjadi tanggungjawab berbagai pihak terkait, seperti dikatakan Shapiro and Purpel (2003) sebagai berikut "... in Germany a law (the Berufsausbildungsgeset?) was passed in 1969 which regulated and unified the vocational training system and codified the shared responsibility of the state, the unions, associations and chambers of trade ... ".

Di USA, penyediaan dana penyelenggaraan pendidikan merupakan masalah dinamis (Lunenberg dan Ornstein, 2000). Pada awal tahun 1930-an pemerintah lokal menanggung sekitar $82,7 \%$ biaya pendidikan. Pada tahun 1999 proporsi bergeser menjadi: pemerintah lokal 39,9\%; negara bagian 43,9\%; Pemerintah Federal 6,1\%; dan sumber lain 10,2\%. Besar dana yang disediakan bervariasi antarnegara bagian. Misal, di New Jersey US\$9318 dan di Utah US\$3670 per siswa per tahun. Lerman (dalam Rauner and Maclean, 2008) menyatakan bahwa “...State's responsibility for financing Vocational Education and Training (VET) is often ambiguous". Pendanaan pendidikan kejuruan di negara sedang berkembang belum seperti yang diharapkan, karena beberapa hal, seperti daya tampung industri lebih kecil dari jumlah siswa yang akan praktik di industri.

Hoeckel (2008) menyatakan bahwa diklat kejuruan yang baik memerlukan biaya dua sampai tiga kali lipat dari pendidikan umum dan makin mahal bila terkait dengan okupasi yang menuntut penguasaan teknologi baru yang spesifik dan cepat berkembang karena peralatan cepat usang sehingga pemutakhiran peralatan lebih sering dilakukan. Mun C. Tsang (1997) mengemukakan bahwa di Malaysia dan Philipina, biaya pendidikan kejuruan hampir tiga kali lipat dari pendidikan umum karena memerlukan material, peralatan, dan fasilitas fisik yang lebih banyak/luas dan komplek, serta rasio gurusiswa yang lebih kecil dibanding pendidikan umum.

USA juga meluncurkan program peningkatan mutu seperti dilaporkan Achieve, Inc (2007) sebagai berikut: “...Obio's competitiveness depends on the ability of its school system to produce an educated and skilled populace". Dilaporkan juga bahwa program peningkatan mutu sekolah berkaitan dengan system pendanaan:

"Enssure that funding is fairly allocated and linked to Accountability ... An excellent, well-managed funding system is critical to provide support at all level of system. Evidence from around the world shows that highperforming countries all follow two commonsense principles. First, they assume a certain minimum amount of money required to educate a student. Second, they acknowledge that some students, because of disadvantages and specific need, will cost more than this minimum amount".

Jadi, perlu dipastikan bahwa dana pendidikan dialokasikan secara fair dan akuntabel, terutama untuk sekelompok peserta didik dari keluarga yang kurang beruntung secara sosial ekonomi atau karena berkebutuhan khusus. 
Dengan demikian, peningkatan mutu melalui SMK-BI merupakan tuntutan yang perlu dilakukan oleh suatu negara dalam menghadapi persaingan global. Konsekuensinya adalah komitmen pemerintah untuk menyediakan dana yang memadai, terutama untuk SMK yang memerlukan dana lebih besar dan sebagian besar peserta didiknya berasal dari golongan ekonomi lemah. Konsekuensi lain adalah manajemen anggaran sekolah yang akuntabel.

Poston (2011) menyatakan bahwa ada empat macam pola penganggaran, yaitu "line-item or function-object budgeting, activity or program budgeting, incremental budgeting, dan performace budgeting". Function-object budgeting dapat mengakomodasi perbedaan kebutuhan biaya antarprogram. Performance-Based Budgeting (anggaran berbasis kinerja) cocok untuk program dengan tujuan unik. Pola ini lebih akuntabel karena menggambarkan lebih jelas hubungan antara aktivitas yang perlu dilakukan, besar biaya yang dibutuhkan, dan metode evaluasi untuk memastikan apakah tujuan telah tercapai. Penyelenggaraan SBI dapat dikategorikan memiliki tujuan unik (mutu lebih tinggi) sehingga lebih tepat menerapkan anggaran berbasis kinerja dan satuan biaya sesuai kebutuhan.

Menurut Daljono (2011), biaya (cost) merupakan pengorbanan sumber ekonomi untuk terlaksananya suatu aktifitas yang memerlukan bahan, tenaga kerja, dan sumber daya overhead dapat dihitung menggunakan metode ABC (activity based costing). Bahan dan tenaga kerja dibedakan menjadi langsung dan tidak langsung. Sumber daya overbead mencakup pemakaian supplies, penyusutan nilai alat dan fasilitas, pemeliharaan alat dan fasilitas, penggunaan daya dan jasa, kegiatan supervisi dan pembinaan, dan bahan yang sulit dirinci.

Abbas Ghozali (2010) melaporkan bahwa biaya operasi pendidikan (BOP) mencakup tidak langsung dan langsung. Biaya tidak langsung antara lain biaya untuk rapat, pemantauan dan kegiatan managemen lain. Biaya langsung mencakup biaya personil dan nonpersonil. Biaya personil adalah gaji dan tunjangan untuk guru dan tenaga kependidikan lainnya. Biaya nonpersonil adalah untuk pengadaan bahan dan alat habis, perawatan fasilitas, dan daya dan jasa seperti listrik, telepon, internet, air dan sejenisnya. Besar dana yang disediakan Pemerintah untuk SMKN di beberapa propinsi Indonesia pada tahun 2004 sudah lebih besar dari SMAN, namun baru sekitar 50\% dari total anggaran sekolah dan besar dana per siswa per tahun disajikan pada Tabel 1.

Tabel 1. Perbandingan Dana per Siswa untuk SMA dan SMK

\begin{tabular}{ccrrr}
\hline \multirow{2}{*}{ Sekolah } & Besar & \multicolumn{3}{c}{ Sumber } \\
\cline { 3 - 5 } & & APBN/D & \multicolumn{1}{l}{ Lain } & \multicolumn{1}{c}{ Total } \\
\hline \multirow{2}{*}{ SMA Negeri } & Rp & 431.000 & 503.000 & 934.000 \\
& $\%$ & 46,15 & 53,65 & 100 \\
SMK Negeri & $\mathrm{Rp}$ & 711.000 & 519.000 & 1.230 .000 \\
& $\%$ & 57,78 & 42,22 & 100 \\
\hline
\end{tabular}

Angka tersebut memperkuat laporan Lewin (2001) bahwa negara sedang berkembang telah berhasil menaikkan angka partisipasi pendidikan, namun belum mampu menaikkan alokasi subsidi dana pendidikan. Akibatnya, mutu pendidikan kejuruan belum memenuhi tuntutan dunia kerja atau biaya SMK yang baik makin tidak terjangkau oleh peserta didik yang berasal dari golongan ekonomi lemah.

Klein et.al (2000) dan Bray and Thomas (1998) menyebutkan bahwa biaya pendidikan mencakup komponen gaji guru dan staf pendukung, pengadaan dan perawatan peralatan, dan bahan habis pakai. Mun C. Tsang membagi biaya pendidikan menjadi tiga, yaitu: institusi, personal peserta didik, dan society. Biaya institusi dibagi menjadi operasi dan kapital. Biaya operasi mencakup biaya personil dan non-personil. Personil terdiri atas guru, administrator, dan staf pendukung. Non-personil mencakup bahan habis, bahan pembelajaran, utilities, perawatan dan perbaikan ringan peralatan, dan layanan lain. Biaya kapital mencakup gedung, peralatan, mebeler, dan lahan. Biaya personal peserta didik mencakup biaya buku pribadi, transportasi, dls. Biaya society tidak dirinci. 
Dengan demikian bisa dimengerti bila biaya SMK lebih mahal dari SMA. Di Filipina, perbandingan recurrent cost (biaya rutin) pendidikan kejuruan hampir dua kali lebih besar dari pendidikan umum seperti disajikan pada Tabel 2 .

Tabel 2. Perbandingan Biaya Sekolah Umum dan Sekolah Kejuruan Teknik

\begin{tabular}{|c|c|c|c|c|c|}
\hline \multirow[b]{2}{*}{ No } & \multirow[b]{2}{*}{ Bidang } & \multicolumn{3}{|c|}{ Persentase (\%) Biaya } & \multirow{2}{*}{$\begin{array}{l}\text { - Jumlah } \\
\text { Per siswa }\end{array}$} \\
\hline & & Staf & $\begin{array}{c}\text { Layanan } \\
\text { siswa }\end{array}$ & Lainnya & \\
\hline 1 & Umum & 85,0 & 13 & 1,4 & 6.080 \\
\hline 2 & TVET & 49,0 & 49 & 1,9 & 11.401 \\
\hline
\end{tabular}

(Peano, Vergel de Dios, Atchoarena, and Mendoza, 2008)

Besar biaya untuk SMK juga terkait dengan jumlah dan jenis alat yang digunakan (Nolker, 1983). Jumlah alat menggunakan satuan "Student Place", yaitu tempat praktek yang dilengkapi dengan alat utama dan alat pendukung untuk pembentukan kompetensi siswa, baik yang digunakan secara individu atau kelompok. Jumlah dan jenis peralatan praktek berdampak pada besar biaya perawatan dan perbaikan, luas gedung laboratorium dan/atau bengkel, serta biaya kapital yang diperlukan. Rumus dasar tentang luas ruang praktek (work place) untuk setiap "Student Place" adalah: $5-7 \mathbf{m}^{2}$ untuk kegiatan pembentukan kompetensi kognitif dan $8-10 \mathrm{~m}^{2}$ untuk praktek pembentukan kompetensi psikomotor. Jumlah guru yang dibutuhkan juga banyak sesuai dengan jenis bidang kompetensi yang dibutuhkan dalam proses pembentukan keterampilan kognitif, maupun keterampilan psikomotor.

Dengan demikian, dapat disimpulkan bahwa sekolah menengah kejuruan (SMK) memerlukan biaya lebih besar dari sekolah menengah umum (SMU) karena memerlukan fasilitas, bahan habis pakai, dan guru lebih banyak. Besar biaya bervariasi antarjenis kompetensi. Namun, peningkatan mutu SMK harus diselenggarakan karena diperlukan peserta didik untuk memperoleh kompetensi sebagai modal mencari pekerjaan dan juga diperlukan dunia usaha dan industri.

Terkait dengan hal tersebut, penelitian ini bertujuan untuk mengungkap besar biaya operasi dan dana operasi nonpersonalia dalam penyusunan anggaran Sekolah Menengah Kejuruan Bertaraf Internasioanl di Daerah Istimewa Yogyakarta.

\section{Metode}

Jenis penelitian ini adalah evaluatif model discrepancy menggunakan pendekatan penghitungan biaya berbasis kegiatan (activity based costing, disingkat $\mathrm{ABC}$ ), namun tidak secara penuh karena kegiatan tertentu tidak ada datanya dan pola penyusunan anggaran berbeda antarsekolah terteliti. ABC dipilih berdasarkan asumsi bahwa program keahlian tertentu memerlukan lebih banyak bahan praktek sehingga biaya dan anggaran lebih besar (Daljono, 2011; dan Hoeckel, 2008). Data dari dua pola anggaran yang berbeda ditransfer ke dalam pola yang sama, yaitu berbasis pengeluaran seperti yang dipakai pada Permendiknas No 69 Tahun 2009.

Penelitian ini dilakukan di SMK-BI di Propinsi Daerah Istimewa Yogyakarta pada tahun 2011, namun data yang diteliti adalah dokumen anggaran sekolah tahun 2010. Populasi penelitian ini adalah sekolah menengah kejuruan negeri (SMKN) di DIY yang sudah dinyatakan sebagai SBI dan RSBI sebanyak 10 sekolah dan tidak dilakukan sampling. Berdasarkan bidangnya, sekolah dikelompokkan menjadi dua, yaitu SMK Teknik dan Non-Teknik. Variabel pada penelitian ini adalah besar biaya operasi nonpersonalia, besar dana tersedia, dan komponen kegiatan pada program pembentukan kompetensi lulusan SMK.

Data dikumpulkan melalui wawancara terstruktur dan kaji dokumen. Wawancara relatif singkat karena pada awal wawancara sudah diketahui bahwa istilah "biaya operasi sekolah" dan Permendiknas No 69 Th 2009 belum dikenal oleh pengelola sekolah, sehingga pengumpulan data fokus melalui kaji dokumen Rencana Kegiatan dan Anggaran Sekolah (RKAS). Sumber data (informan) 
adalah kepala sekolah, petugas yang ditunjuk kepala sekolah untuk memegang dokumen RKAS dan pengelola anggaran sekolah. Data dianalisis secara deskriptif kualitatif dan kuantitatif. Analisis kualitatif digunakan untuk mengelompokkan jenis pengeluaran. Analisis kuantitatif digunakan untuk menganalisis besar anggaran. Validasi data dilakukan melalui triangulasi sumber data primer, yaitu dokumen diperoleh langsung dari (a) pimpinan sekolah (kepala dan wakil kepala sekolah), (b) pengelola anggaran sekolah, dan (c) kepala Tata Usaha.

\section{Definisi Operasional}

Dalam penelitian ini, ada beberapa hal yang perlu didefinisikan terlebih dahulu, yaitu: (a) dana adalah rupiah yang tersedia untuk suatu kegiatan; (b) anggaran adalah alokasi dana untuk suatu kegiatan yang direncanakan; (c) biaya adalah rupiah yang perlu dibayarkan untuk suatu komponen kegiatan; (d) Biaya personalia adalah gaji dan tunjangan melekat yang harus dibayarkan kepada personil pelaksana kegiatan; (e) biaya operasi nonpersonalia adalah rupiah yang harus dibayar untuk bahan dan alat habis pakai (BAHP) dan jasa yang diperlukan guna terselenggaranya kegiatan yang meliputi: (1) alat tulis sekolah (ATS) untuk pengelolaan sekolah dan proses belajar; (2) sumber daya listrik, air, jasa telekomunikasi; (3) pemeliharaan dan perbaikan ringan sarana dan prasarana; (4) transportasi perjalanan dinas pendidik dan tenaga kependidikan; (5) konsumsi untuk rapat-rapat, perlombaan dsj; (6) asuransi keselamatan sekolah, pendidik, tenaga kependidikan, dan siswa (peserta didik), kecelakaan siswa saat praktek kerja di industri, dll; (7) jasa pembina kegiatan ekstra kurikuler, (8) BAHP untuk kegiatan praktikum, kebersihan, olah raga, dsj; (9) biaya praktek kerja industri dan uji kompetensi; (10) evaluasi hasil belajar dan pelaporan sekolah kepada pihak yang berwenang; (11) penyusunan kurikulum; (12) kemitraan; (13) pengelolaan, dan (14) kegiatan yang belum teridentifikasi tetapi perlu dilakukan untuk keberhasilan suatu program.

\section{Hasil}

Hasil penelitian mencakup acuan penyusunan RKAS, hasil penghitungan besar $\mathrm{BO}$ nonpersonalia, dan distribusi penggunaan dana berdasarkan hasil kaji dokumen anggaran SMKN-BI/RSBI atau unggulan di DIY.

Acuan Penyusunan Rencana Kegiatan Anggaran Sekolah (RKAS) diketahui melalui wawancara. Hasil wawancara tentang acuan penyusunan RKAS disajikan pada Tabel 3.

Tabel 3. Acuan Penyusunan RKAS

\begin{tabular}{|c|c|c|c|c|}
\hline \multirow{2}{*}{ No } & \multirow{2}{*}{$\begin{array}{c}\text { Acuan Penyusunan Anggaran } \\
\text { Operasi }\end{array}$} & \multicolumn{2}{|c|}{ Jawaban } & \multirow{2}{*}{ Ringkasan Hasil Wawancara } \\
\hline & & $\mathrm{Ya}$ & Tidak & \\
\hline \multirow[t]{2}{*}{1} & Apakah sudah mengacu pada & & & Pengelola sekolah belum tahu bahwa ada \\
\hline & Permendiknas No 69 Th 2009 & 0 & 9 & $\begin{array}{l}\text { Permendiknas tersebut sehingga belum ada yang } \\
\text { menggunakannya sebagai acuan. }\end{array}$ \\
\hline 2 & $\begin{array}{l}\text { Bila tidak mengacu pada } \\
\text { Permendiknas No } 69 \text { Th 209, } \\
\text { Apa acuan penyusunan } \\
\text { anggaran sekolah?” }\end{array}$ & 9 & 0 & $\begin{array}{l}\text { Pengelola sekolah harus mengacu pada pola yang } \\
\text { ditetapkan oleh Pemerintah Kabupaten/Kota karena } \\
\text { sebagai syarat pencairan dana dari pemerintah dan } \\
\text { dasar pertanggungjawaban anggaran sekolah. }\end{array}$ \\
\hline 3 & $\begin{array}{l}\text { Apakah pernah menghitung } \\
\text { Besar Biaya per Peserta Didik } \\
\text { per PK/KK }\end{array}$ & 0 & 9 & $\begin{array}{l}\text { Belum ada pengelola sekolah yang pernah menghitung, } \\
\text { kecuali satu sekolah namun penghitungan tidak } \\
\text { diselesaikan karena dana sudah turun. }\end{array}$ \\
\hline 4 & $\begin{array}{l}\text { Apa ada Perbedaan anggaran } \\
\text { antarPK/KK }\end{array}$ & - & - & $\begin{array}{l}\text { Belum ada yang membedakan anggaran antar } \\
\text { program/kompetensi (PK/KK). }\end{array}$ \\
\hline 5 & Lainnya & 0 & 0 & \\
\hline
\end{tabular}


Hasil wawancara tersebut menunjukkan bahwa: a) pengelola sekolah belum tahu bahwa ada Permendiknas No 69 Th 2009 sehingga belum menggunakannya dalam menyusun anggaran sekolah; b) pengelola SMK-BI belum menghitung biaya operasi (BO) per program atau kompetensi (PK/ $\mathrm{KK}$ ) sebagai dasar penyusunan anggaran sekolah; c) anggaran sekolah disusun ber- dasarkan arahan Dinas Pendidikan Kodya/ Kabupaten.

Kaji dokumen menghasilkan data bahwa ada dua pola pengelompokan kegiatan pada penyusunan RKAS, yaitu berorientasi pada: (1) pemenuhan Standar Nasional Pendidikan (SPN) dan (2) bidang garapan Wakil Kepala Sekolah/TU Sekolah disajikan pada Tabel 4 dan Tabel 5.

Tabel 4. Pengelompokan Kegiatan dan Anggaran Sekolah Berorientasi pada Pemenuhan Standar Nasional Pendidikan (SPN)

\begin{tabular}{|c|c|c|}
\hline \multicolumn{3}{|r|}{ Program/Kegiatan dan Anggaran } \\
\hline \multirow[t]{5}{*}{1} & \multicolumn{2}{|c|}{ Standar Isi ( SI ) } \\
\hline & 1 & Telaah/Analisis Standar Isi \\
\hline & 2 & Pengembangan Kurikulum \\
\hline & 3 & Pengembangan Silabus dan RPP \\
\hline & 4 & Dst \\
\hline \multirow[t]{5}{*}{2} & \multicolumn{2}{|c|}{ Standar Proses } \\
\hline & 1 & Penyusunan Perangkat Administrasi Pembelajaran \\
\hline & 2 & Penyusunan Bahan Ajar \\
\hline & 3 & Tambahan Pelajaran (Les) \\
\hline & 4 & dst \\
\hline \multirow[t]{5}{*}{3} & \multicolumn{2}{|c|}{ Standar Kompetensi Kelulusan ( SKL) } \\
\hline & 1 & Telaah / Bedah SKL \\
\hline & 2 & Pengembangan SKL \\
\hline & 3 & Penyusunan KKM \\
\hline & 4 & dst \\
\hline \multirow[t]{5}{*}{4} & \multicolumn{2}{|c|}{ Standar Pendidik dan Tenaga Kependidikan } \\
\hline & 1 & Kegiatan MKKS/KKKS/K3SK \\
\hline & 2 & Kegiatan KKG/MGMP \\
\hline & 3 & Pelatihan Penggunaan Media Pembelajaran \\
\hline & 4 & Dst \\
\hline \multirow[t]{5}{*}{5} & \multicolumn{2}{|c|}{ Standar Sarana dan Prasarana } \\
\hline & 1 & Pemeliharaan Lingkungan Sekolah \\
\hline & 2 & Penataan Taman Sekolah \\
\hline & 3 & Pengadaan Alat-Alat Kebersihan \\
\hline & 4 & dst \\
\hline \multirow[t]{5}{*}{6} & \multicolumn{2}{|c|}{ Standar Pengelolaan } \\
\hline & 1 & Kegiatan Home Visit \\
\hline & 2 & Penelusuran Tamatan \\
\hline & 3 & Penerimaan Peserta Didik Baru (PPDB) \\
\hline & 4 & dst \\
\hline \multirow[t]{5}{*}{7} & \multicolumn{2}{|c|}{ Standar Pembiayaan Pendidikan } \\
\hline & 1 & Pemberian Beasiswa (Retrivel/Rapus/Prestasi) \\
\hline & 2 & Penghargaan Guru Berprestasi \\
\hline & 3 & Partnership \\
\hline & 4 & Dst \\
\hline \multirow[t]{5}{*}{8} & \multicolumn{2}{|c|}{ Standar Penilaian Pendidikan } \\
\hline & 1 & Ulangan Harian \\
\hline & 2 & Ulangan Umum Tengah Semester (UTS ) \\
\hline & 3 & Ulangan Umum Akhir Semester (UAS ) \\
\hline & 4 & Dst \\
\hline
\end{tabular}


Tabel 5. Pengelompokan Kegiatan dan Anggaran Berorientasi pada Bidang Garapan Wakil Kepala Sekolah/TU Sekolah.

\begin{tabular}{llcll}
\hline No & \multicolumn{1}{c}{ Bidang Kegiatan } & No & Program & Volume \\
\hline 1 & WK I: SARPRAS & 1 & Rapat & 6 kegiatan \\
& & 2 & Transport/Kesejaht. & 11 kegiatan \\
& & 3 & Pengadaan Sarpras & 49 kegiatan \\
& & 4 & Dst & 21 kegiatan \\
\hline 2 & WK II: KURIKULUM & & & 19 kegiatan \\
\hline 3 & WK III: KESISWAAN & 1 & Osis & 5 kegiatan \\
& & 2 & Pramuka & 4 kegiatan \\
& & 3 & Keagamaan & 6 kegiatan \\
& & 4 & UKS & 11 kegiatan \\
\hline 4 & WK IV: HUMAS & 5 & Dst & 3 kegiatan \\
\hline 5 & WMM & & & 4 kegiatan \\
& (Wakil Manajemen Mutu) & 2 & Audit Internal & 9 kegiatan \\
& & 3 & Sertifikasi & \\
\hline 6 & SUB BAG T.U. & 4 & Dst & kegiatan \\
& & 2 & Gapat/Konsumsi & \\
& & 3 & Daya \& Jasa & 23 butir \\
\hline
\end{tabular}

RKAS kemudian dikaji dan ditransfer menjadi komponen biaya untuk menghitung besar $\mathrm{BO}$ non personalia seperti pola penghitungan pada Permendiknas No 69 Tahun 2009. Transfer menghasilkan 14 jenis komponen biaya sekolah disajikan pada Tabel 6.
Empat belas komponen BO sekolah tersebut mencakup 10 komponen biaya pada Permendiknas dan empat jenis komponen lain, yaitu: (a) penyusunan dan Benchmark kurikulum dan bahan ajar dg OECD, (b) kemitraan dengan industri dan sister school, (c) pengelolaan, dan (d) kegiatan lain, seperti disajikan Tabel 6.

Tabel 6. Komponen Biaya Operasi Sekolah

\begin{tabular}{l} 
Jenis Komponen \\
\hline 1. Pengadaan alat tulis sekolah \\
2. Biaya daya dan jasa \\
3. Biaya pemeliharaan dan perbaikan ringan \\
4. Biaya transportasi dan perjalanan dinas \\
5. Biaya konsumsi \\
6. Biaya asuransi \\
7. Pembina kegiatan ekstra kurikuler \\
8. Bahan dan alat habis pakai \\
9. Biaya Prakerin dan Uji kompetensi \\
10. Biaya evaluasi hasil belajar dan pelaporan \\
11. Biaya penyusunan dan Benchmark kurikulum dengan OECD \\
12. Biaya kemitraan dengan industri dan sister school \\
13. Biaya pengelolaan \\
14. Biaya kegiatan lain
\end{tabular}


Besar dana tersedia per sumber dana per peserta didik diketahui dengan mengkaji dokumen. Kaji dokumen RKAS juga menghasilkan data besar dana per sekolah per sumber dana kemudian diolah menjadi per peserta didik (siswa) disajikan pada Tabel 7 untuk SMK Non-Teknik dan Tabel 9 untuk SMK Teknik sebagai berikut.

Tabel 7. Besar Dana per Sumber per Sekolah per Siswa pada SMK Non-Teknik

\begin{tabular}{|c|c|c|c|c|c|c|c|}
\hline & \multirow{2}{*}{ Sumber Dana } & \multicolumn{6}{|c|}{ Besar Dana per Sekolah per Siswa per Tahun (Rp) } \\
\hline & & SMKN A & SMKN B & SMKN C & SMKN D & SMKN E & Rerata \\
\hline A & Total per Siswa & 6.994 .097 & 6.497 .311 & 7.018 .490 & 9.547 .881 & - & 7.514 .445 \\
\hline B & Diknas Kodya/ Kabupaten & & & & & & \\
\hline 1 & $\begin{array}{l}\text { Gaji \& tunjangan PNS pendidik } \\
\& \text { tenaga kependidikan lain }\end{array}$ & 4.408 .327 & 3.443 .218 & 3.872 .743 & 3.800 .046 & $\begin{array}{l}\text { Tidak ada } \\
\text { data }\end{array}$ & 3.881 .084 \\
\hline 2 & Selain gaji PNS & 37.714 & 506.339 & 627.782 & 764.106 & 920.549 & 571.298 \\
\hline $\mathrm{C}$ & Diknas Prop & 126.330 & 210.549 & 59.493 & 154.709 & 135.685 & 137.353 \\
\hline $\mathrm{D}$ & APBN Pusat & & & & & & \\
\hline 1 & INVEST & 0 & 0 & 0 & 0 & 0 & \\
\hline 2 & NON-INVEST & 79.115 & 127.559 & 241.475 & 137.395 & 226.475 & 162.404 \\
\hline & B.2. $+\mathrm{C}+\mathrm{D} 2$ & 243.159 & 844.448 & 928.749 & 1.056 .210 & 1.282 .710 & 871.055 \\
\hline $\mathrm{E}$ & Sponsor/UPJ & & & & & & \\
\hline $\mathrm{F}$ & Komite Sekolah & 2.342 .611 & 2.209 .646 & 1.288 .248 & 3.635 .414 & 2.709 .041 & 2.436 .992 \\
\hline G & Nonpersonalia Total per Siswa & 2.585 .770 & 3.054 .093 & 3.145 .747 & 5.747 .834 & 3.991 .751 & 3.705 .039 \\
\hline
\end{tabular}

Tabel 8. Persentase Dana per Sumber per Sekolah per Siswa SMK Non-Teknik

\begin{tabular}{|c|c|c|c|c|c|c|c|}
\hline & \multirow{2}{*}{ Sumber Dana } & \multicolumn{6}{|c|}{ Persentase per Sekolah per Siswa per Tahun } \\
\hline & & SMKN A & SMKN B & SMKN C & SMKN D & SMKN E & Rerata \\
\hline A & Total per Siswa & $100 \%$ & $100 \%$ & $100 \%$ & $100 \%$ & Tidak ada data & $100 \%$ \\
\hline B & Diknas Kodya/Kab. & & & & & & \\
\hline 1 & Gaji \& tunj. PNS & $63,0 \%$ & $53,0 \%$ & $55,18 \%$ & $39,80 \%$ & Tidak ada data & $52,75 \%$ \\
\hline 2 & Selain gaji PNS & $0,54 \%$ & $7,79 \%$ & $8,94 \%$ & $8,00 \%$ & Tidak dihitung & $6,32 \%$ \\
\hline $\mathrm{C}$ & Diknas Prop & $1,81 \%$ & $3,24 \%$ & $0,85 \%$ & $1,62 \%$ & Tidak dihitung & $1,88 \%$ \\
\hline $\mathrm{D}$ & APBN Pusat & & & & & & \\
\hline 1 & INVEST & - & - & - & - & & \\
\hline 2 & Non-INVEST & $1,13 \%$ & $1,96 \%$ & $3,44 \%$ & $1,44 \%$ & Tidak dihitung & $1,99 \%$ \\
\hline & B.2. + C + D2 & $3,48 \%$ & $13,00 \%$ & $13,23 \%$ & $11,06 \%$ & Tidak dihitung & $10,19 \%$ \\
\hline $\mathrm{E}$ & Sponsor/UPJ & & & & & & \\
\hline $\mathrm{F}$ & Komite Sekolah & $33,49 \%$ & $34,01 \%$ & $18,36 \%$ & $38,08 \%$ & Tidak dihitung & $30,98 \%$ \\
\hline G & Nonpersonalia Total per Siswa & $36,97 \%$ & $47,01 \%$ & $44,82 \%$ & $60,20 \%$ & Tidak dihitung & $47,25 \%$ \\
\hline
\end{tabular}


Tabel 9. Besar Dana per Sumber per Sekolah per Siswa pada SMK Teknik

\begin{tabular}{|c|c|c|c|c|c|c|}
\hline & \multirow{2}{*}{ Sumber } & \multicolumn{5}{|c|}{ Besar Dana per Sekolah per Siswa per Tahun (Rp) } \\
\hline & & SMKN A & SMKN B & SMKN C & SMKN D & Rerata \\
\hline A & Total per Siswa & 10.806 .805 & 7.326 .606 & 7.370 .993 & 10.905 .482 & 9.102 .472 \\
\hline B & Diknas Kodya/ Kabupaten & & & & & \\
\hline 1 & Gaji \& tunjangan PNS & 4.622 .795 & 4.116 .344 & 5.110 .672 & 4.668 .550 & 4.629.591 \\
\hline 2 & Selain gaji PNS & 177.917 & & 433.372 & 635.845 & 415.711 \\
\hline $\mathrm{C}$ & Diknas Prop & 30.711 & & 52.550 & 206.875 & 96.712 \\
\hline $\mathrm{D}$ & APBN Pusat & & & & & \\
\hline 1 & INVEST & 2.059 .139 & - & - & 1.632 .396 & 1.845 .767 \\
\hline 2 & Non INVEST & 123.198 & & 12.550 & 176.626 & 104.125 \\
\hline & B.2. $+\mathrm{C}+\mathrm{D} 2$ & 331.825 & 1.347.278 & 498.473 & 1.019 .346 & 799.231 \\
\hline & Sponsor/UPJ & & & 235.588 & & \\
\hline F & Komite Sekolah & 3.793 .046 & 1.862 .983 & 1.526 .260 & 3.585 .190 & 2.691 .870 \\
\hline G & Nonpersonalia Total per Siswa & 6.184 .010 & 3.210 .262 & 2.260 .320 & 6.236 .932 & 4.472 .881 \\
\hline
\end{tabular}

Tabel 10. Persentase Dana per Sumber per Sekolah per Siswa pada SMK Teknik

\begin{tabular}{|c|c|c|c|c|c|c|}
\hline & \multirow{2}{*}{ Sumber } & \multicolumn{5}{|c|}{ Persentase per Sekolah per Siswa per Tahun } \\
\hline & & SMKN A & SMKN B & SMKN C & SMKN D & Rerata \\
\hline A & Total per Siswa & $100 \%$ & $100 \%$ & $100 \%$ & $100 \%$ & $100 \%$ \\
\hline B & Diknas Kodya/Kab. & & & & & \\
\hline 1 & Gaji \& tunj. PNS & $42,78 \%$ & $56,18 \%$ & $69,33 \%$ & $42,81 \%$ & $52,78 \%$ \\
\hline 2 & Selain gaji PNS & $1,65 \%$ & & $5,88 \%$ & $5,83 \%$ & $3,34 \%$ \\
\hline $\mathrm{C}$ & Diknas Prop & $0,28 \%$ & & $0,71 \%$ & $1,90 \%$ & $0,72 \%$ \\
\hline $\mathrm{D}$ & APBN Pusat & & & & & \\
\hline 1 & INVEST & $19,05 \%$ & & & $14,97 \%$ & $17,01 \%$ \\
\hline 2 & Non-INVEST & $1,14 \%$ & & $0,17 \%$ & $1,62 \%$ & $0,73 \%$ \\
\hline & B.2. $+\mathrm{C}+\mathrm{D} 2$ & $3,1 \%$ & $18,39 \%$ & $6,76 \%$ & $9,35 \%$ & $9,39 \%$ \\
\hline $\mathrm{E}$ & Sponsor/UPJ & & & $3.2 \%$ & & $3.2 \%$ \\
\hline $\mathrm{F}$ & Komite Sekolah & $35,10 \%$ & $25,43 \%$ & $20,71 \%$ & $32,88 \%$ & $28,53 \%$ \\
\hline G & Nonpersonalia Total per Siswa & $57,22 \%$ & $43,82 \%$ & $30,67 \%$ & $57,19 \%$ & $47,22 \%$ \\
\hline
\end{tabular}

Distribusi dana untuk biaya operasi non-gaji per komponen diketahui dengan mengkaji dokumen. Distribusi dana untuk biaya operasi sekolah non-gaji per kompo- nen disajikan dalam Tabel 11 sampai Tabel 14 sebagai berikut. Salah satu komponen pengeluaran tersebut adalah untuk bahan dan alat habis pakai (BHAP). 
Tabel 11. Besar Biaya Operasi Non-Gaji per Komponen per Sekolah per Siswa per Tahun pada SMK Kelompok Non-Teknik

\begin{tabular}{|c|c|c|c|c|c|c|c|}
\hline \multirow{2}{*}{ No } & \multirow{2}{*}{ Komponen } & \multicolumn{6}{|c|}{ Besar Biaya per Sekolah per Siswa per Tahun (Rp) } \\
\hline & & SMKN A & SMKN B & SMKN C & SMKN D & SMKN E & Rerata \\
\hline 1 & Alat Tulis Sekolah & 43.956 & 48.840 & 79.189 & 81.066 & - & 63.263 \\
\hline 2 & Daya dan Jasa & 65.934 & 77.604 & 100.724 & 183.799 & - & 107.015 \\
\hline 3 & $\begin{array}{l}\text { Pemeliharaan \& } \\
\text { perbaikan ringan }\end{array}$ & 118.095 & 404.094 & 192.906 & 237.409 & - & 238.126 \\
\hline 4 & Transportasi & 80.987 & 28.816 & 35.477 & 56.159 & - & 50.360 \\
\hline 5 & Konsumsi & 27.473 & 13.187 & 57.047 & - & - & 24.426 \\
\hline 6 & Asuransi & - & - & - & - & - & - \\
\hline 7 & Ekstra Kurikuler & 174.780 & 247.911 & 356.511 & 526.069 & - & 326.318 \\
\hline 8 & BAHP & 96.492 & 61.050 & 150.621 & 584.477 & 380.041 & 254.536 \\
\hline 9 & Prakerin/Uji Kom. & 101.260 & 125.379 & 85.538 & 317.108 & 25.410 & 130.939 \\
\hline 10 & Evaluasi \& Pelpr. & 132.001 & 260.632 & 155.554 & 185.142 & 19.115 & 183.332 \\
\hline 11 & Kurikulum & 403.024 & 375.569 & 47.052 & 302.007 & - & 281.913 \\
\hline 12 & Kemitraan & 46.740 & 74.481 & 55.432 & 228.171 & - & 101.206 \\
\hline 13 & Kegiatan lain & 113.626 & 41.852 & 125.395 & 111.643 & - & 98.129 \\
\hline 14 & Pengelolaan & 72.161 & 309.234 & 95.723 & 207.792 & - & 171.228 \\
\hline & Berbagai kegiatan & & & & & 2.303 .431 & \\
\hline & tal Biaya Operasi & 1.476 .530 & 2.068 .649 & 1.537 .167 & 3.020 .841 & 2.727 .997 & 2.166 .237 \\
\hline
\end{tabular}

Tabel 12. Persentase Biaya Operasi Non-Gaji per Komponen per Sekolah per Siswa per Tahun pada SMK Kelompok Nok-Teknik

\begin{tabular}{|c|c|c|c|c|c|c|c|}
\hline \multirow[b]{2}{*}{ No } & \multirow{2}{*}{ Total } & \multicolumn{6}{|c|}{ Dana per Sekolah per Siswa per Tahun $(\%)$} \\
\hline & & SMKN A & SMKN B & SMKN C & SMKN D & SMKN E & Rerata \\
\hline 1 & Alat Tulis Sekolah & $3,0 \%$ & $2,4 \%$ & $5,2 \%$ & $2,7 \%$ & & $3,33 \%$ \\
\hline 2 & Daya dan Jasa & $4,5 \%$ & $3,8 \%$ & $6,6 \%$ & $6,1 \%$ & & $5,25 \%$ \\
\hline 3 & $\begin{array}{l}\text { Pemeliharaan \& } \\
\text { perbaikan ringan }\end{array}$ & $8,0 \%$ & $19,5 \%$ & $12,5 \%$ & $7,9 \%$ & & $11,98 \%$ \\
\hline 4 & Transportasi & $5,5 \%$ & $1,4 \%$ & $2,3 \%$ & $1,9 \%$ & & $2,78 \%$ \\
\hline 5 & Konsumsi & $1,9 \%$ & $0,6 \%$ & $3,7 \%$ & & & $1,55 \%$ \\
\hline 6 & Asuransi & & $0,0 \%$ & & & & $0,00 \%$ \\
\hline 7 & Ekstra Kurikuler & $11,8 \%$ & $12,0 \%$ & $23,2 \%$ & $17,4 \%$ & & $16,10 \%$ \\
\hline 8 & BAHP & $6,5 \%$ & $3,0 \%$ & $9,8 \%$ & $19,3 \%$ & $13,9 \%$ & $10,50 \%$ \\
\hline 9 & Prakerin/Uji Komp. & $6,9 \%$ & $6,1 \%$ & $5,6 \%$ & $10,5 \%$ & $0,9 \%$ & $6,00 \%$ \\
\hline 10 & Evaluasi \& Pelaporn & $8,9 \%$ & $12,6 \%$ & $10,1 \%$ & $6,1 \%$ & $0,7 \%$ & $7,68 \%$ \\
\hline 11 & Kurikulum & $27,3 \%$ & $18,2 \%$ & $3,1 \%$ & $10,0 \%$ & & $14,65 \%$ \\
\hline 12 & Kemitraan & $3,2 \%$ & $3,6 \%$ & $3,6 \%$ & $7,6 \%$ & & $4,50 \%$ \\
\hline 13 & Kegiatan lain & $7,7 \%$ & $2,0 \%$ & $8,2 \%$ & $3,7 \%$ & & $5,40 \%$ \\
\hline 14 & Pengelolaan & $4,9 \%$ & $14,9 \%$ & $6,2 \%$ & $6,9 \%$ & & $8,23 \%$ \\
\hline & Berbagai kegiatan & & & & & $84,4 \%$ & \\
\hline & Total Biaya Operasi & $100 \%$ & $100 \%$ & $100 \%$ & $100 \%$ & $100 \%$ & $100 \%$ \\
\hline
\end{tabular}


Tabel 13. Besar Biaya Operasi Non-Gaji per Komponen per Sekolah per Siswa per Tahun pada SMK Kelompok Teknik

\begin{tabular}{|c|c|c|c|c|c|c|}
\hline \multirow[b]{2}{*}{ No } & \multirow{2}{*}{ Komponen } & \multicolumn{5}{|c|}{ Dana per Sekolah per Siswa per Tahun(Rp) } \\
\hline & & SMKN A & SMKN B & SMKN C & SMKN D & Rerata \\
\hline 1 & Alat Tulis Sekolah & 97.949 & 73.534 & 27.057 & 87.936 & 71.619 \\
\hline 2 & Daya dan Jasa & 122.008 & 98.011 & 83.077 & 85.513 & 97.152 \\
\hline 3 & Pemeliharaan \& perbaikan ringan & 186.472 & 323.888 & 97.952 & 192.818 & 200.283 \\
\hline 4 & Transportasi & 75.646 & 111.360 & 87.759 & 39.870 & 78.659 \\
\hline 5 & Konsumsi & 33.433 & 47.541 & 38.096 & - & 39.690 \\
\hline 6 & Asuransi & - & - & 5.796 & - & 5.796 \\
\hline 7 & Ekstra Kurikuler & 310.251 & 131.906 & 227.737 & 521.321 & 297.804 \\
\hline 8 & BAHP & 445.824 & 380.436 & 309.119 & 586.380 & 430.440 \\
\hline 9 & Prakerin/Uji Komp. & 264.482 & 113.260 & 84.467 & 528.679 & 247.722 \\
\hline 10 & Evaluasi \& Pelaporan & 304.845 & 101.393 & 181.258 & 99.976 & 171.868 \\
\hline 11 & Kurikulum & 341.742 & 269.793 & 315.770 & 548.093 & 368.850 \\
\hline 12 & Kemitraan & 61.093 & 32.804 & 38.640 & 80.986 & 53.381 \\
\hline 13 & Kegiatan lain & 76.074 & 49.724 & 96.882 & 279.899 & 125.645 \\
\hline 14 & Pengelolaan & 190.385 & 70.787 & 35.982 & 152.560 & 112.429 \\
\hline Tota & l Biaya Operasi & 2.510 .204 & 1.804 .437 & 1.629 .592 & 3.204 .032 & 2.287 .66 \\
\hline
\end{tabular}

Tabel 14. Persentase Biaya Operasi Non-Gaji per Komponen per Sekolah per Siswa per Tahun pada SMK Kelompok Teknik

\begin{tabular}{|c|c|c|c|c|c|c|}
\hline \multirow{2}{*}{ No } & \multirow{2}{*}{ Komponen } & \multicolumn{5}{|c|}{ Dana per Sekolah per Siswa per Tahun (\%) } \\
\hline & & SMKN A & SMKN B & SMKN C & SMKN D & Rerata \\
\hline 1 & Alat Tulis Sekolah & $3,9 \%$ & $4,1 \%$ & $1,7 \%$ & $5 \%$ & $3,7 \%$ \\
\hline 2 & Daya dan Jasa & $4,9 \%$ & $5,4 \%$ & $5,1 \%$ & & $3,9 \%$ \\
\hline 3 & Pemeliharaan \& perbaikan ringan & $7,4 \%$ & $17,9 \%$ & $7,4 \%$ & & $8,2 \%$ \\
\hline 4 & Transportasi & $3,0 \%$ & $6,2 \%$ & $5,4 \%$ & $1 \%$ & $4,0 \%$ \\
\hline 5 & Konsumsi & $1,3 \%$ & $2,6 \%$ & $0,5 \%$ & & $1,1 \%$ \\
\hline 6 & Asuransi & & & $0,4 \%$ & & $0,1 \%$ \\
\hline 7 & Ekstra Kurikuler & $12,4 \%$ & $7,3 \%$ & $14,3 \%$ & $17 \%$ & $12,8 \%$ \\
\hline 8 & BAHP & $17,8 \%$ & $21,1 \%$ & $18,9 \%$ & $20 \%$ & $19,4 \%$ \\
\hline 9 & Prakerin/Uji Komp. & $10,5 \%$ & $6,3 \%$ & $5,18 \%$ & $18 \%$ & $9,9 \%$ \\
\hline 10 & Evaluasi \& Pelaporan & $12,1 \%$ & $5,6 \%$ & $11,1 \%$ & $3 \%$ & $8,1 \%$ \\
\hline 11 & Kurikulum & $13,6 \%$ & $15,0 \%$ & $19,4 \%$ & $18 \%$ & $16,6 \%$ \\
\hline 12 & Kemitraan & $2,4 \%$ & $1,8 \%$ & $2,4 \%$ & $3 \%$ & $2,3 \%$ \\
\hline 13 & Kegiatan lain & $3,0 \%$ & $2,8 \%$ & $6,2 \%$ & $9 \%$ & $5,3 \%$ \\
\hline 14 & Pengelolaan & $7,6 \%$ & $3,9 \%$ & $2,2 \%$ & $5 \%$ & $4,7 \%$ \\
\hline Tota & l Biaya Operasi & $100 \%$ & $100 \%$ & $100 \%$ & $100 \%$ & $100 \%$ \\
\hline
\end{tabular}


Pembahasan

Panduan SMK-BI mengamanatkan sekolah untuk menghasilkan lulusan yang lebih baik dari lulusan SSN dengan "Menerapkan standar kelulusan lebih tinggi dari Standar Kompetensi Lulusan" berarti memiliki tujuan dengan kriteria berbeda (unik). Menurut Poston (2011), ada konsekuensi dari penetapan tujuan unik, yaitu (a) uraian program dan kegiatan berbeda (unik) dan (b) anggaran disusun berbasis kinerja (performance based budgeting) atau pencapaian tujuan dan satuan biaya (unit cost) berdasarkan program tersusun. Permendiknas No 69 Tahun 2009 mengamantakan satuan biaya SMK berbeda antar Program Keahlian (PK) dengan indikator besar biaya untuk komponen bahan dan alat habis pakai (BAHP).

Namun, hasil telaah dokumen RKAS SMK-BI di DIY menemukan bahwa satuan $\mathrm{BO}$ nonpersonalia tidak berbasis $\mathrm{BO}$ per PK dan tidak berorientasi pada tercapainya kompetensi lulusan lebih baik dari SMK SSN seperti tertulis pada panduan SMK-BI. RKAS yang berorientasi pada Standar $\mathrm{Na}$ sional Pendidikan (SNP), periksa Tabel 4, memuat kegiatan peningkatan mutu lulusan melalui "Benchmark kurikulum dengan kurikulum sekolah dari OECD", namun belum menyebutkan kriteria "mutu lulusan di atas Standar Kompetensi Lulusan" sebagai target program dan nampak program untuk mencapainya. RKAS yang berorientasi pada bidang garap wakil kepala sekolah, periksa Tabel 5, juga belum memuat indikasi tersebut.

Besar BO nonpersonalia SMK-BI di DIY (Tabel 7 dan Tabel 9) hampir sama dengan angka pada SMK SSN (Permendiknas No 69 Tahun 2009). Besar BO nonpersonalia untuk SMK-BI kelompok bidang nonteknik adalah: rerata $\mathrm{Rp} 2.166 .237,00$ (terendah Rp1.476.530,00 dan tertinggi Rp3.020.841,00), sedangkan SMK SSN adalah terendah Rp1.860.000,00 dan tertinggi Rp2.050.000,00 per siswa per tahun. Jadi, besar BO personalia SMK-BI tertinggi sedikit lebih tinggi, tetapi yang terendah lebih rendah dari SMK SSN.
Besar BO nonpersonalia SMK-BI kelompok bidang teknik (Tabel 9) adalah: rerata Rp2.287.066,00 (terendah Rp1.629.592,00 dan tertinggi Rp3.204.032,00), sedangkan SMK SSN adalah terendah Rp1.870.000,00 dan tertinggi Rp2.510.000,00 per siswa per tahun. Jadi, besar BO nonpersonalia SMKBI yang tertinggi sudah lebih tinggi, tetapi yang terendah masih lebih rendah dari SMK SSN.

Persentase BO nonpersonalia per komponen per sekolah per siswa per tahun (Tabel 8 dan Tabel 10) menunjukkan bahwa persentase biaya komponen BAHP pada SMK-BI di DIY kelompok bidang nonteknik adalah 10,50\% dan untuk kelompok bidang teknik adalah 19,40\%. Persentase tersebut tersebut sedikit lebih kecil dari persentase yang diamanatkan pada standar biaya SMK SSN, yaitu terendah 10\% dan tertinggi 20\% untuk SMK kelompok bidang non-teknik dan terendah 10\% dan tertinggi 30\% untuk kelompok bidang teknik.

Dilihat dari sumber dan besar dana per siswa per tahun (Tabel 7 dan Tabel 9) pada butir B2 $+\mathrm{C}+\mathrm{D} 2)$, dapat diketahui bahwa persentase dana dari Pemerintah (Pusat, propinsi, dan kabupaten/kota) relatif kecil dibanding kebutuhan, yaitu untuk kelompok bidang non-teknikyaitu sebesar Rp871.055,00 $(15,30 \%)$ dan untuk kelompok bidang teknik justru lebih kecil yaitu sebesar Rp799,231,00 (9,40\%). Dengan demikian, data tersebut memperkuat pendapat pengelola dan guru SMK-BI bahwa sekolah belum merasakan adanya peningkatan dana setelah berstatus sebagai SMK-BI.

Bila dilacak lebih rinci nampak pemerintah kabupaten/kota tertentu hanya mampu menyediakan dana $\mathrm{BO}$ nonpersonalia sebesar Rp178.000,00 per siswa per tahun. Jumlah dana tersebut tidak cukup untuk biaya BAHP, yaitu sebesar Rp254.536,00 per siswa per tahun untuk SMK kelompok bidang non-teknik dan Rp436.440,00 per siswa per tahun untuk kelompok bidang teknik (Tabel 14 dan Tabel 16 butir nomor 8). Akibatnya, komite sekolah (orang tua peserta didik) harus menanggung $\mathrm{BO}$ nonpersonalia penyelenggaraan 
SMK-BI sebesar 90,60\% untuk kelompok bidang teknik atau $84,70 \%$ untuk nonteknik.

Kondisi demikian menunjukkan bahwa Pemerintah kurang atau tidak konsekuen dalam menyelenggarakan program peningkatan mutu lulusan seperti SMK-BI dan sejenisnya dengan tidak menyediakan dana yang memadai, khususnya untuk peserta didik dari kelompok ekonomi lemah. Akibatnya, timbul polemik tentang mahalnya biaya SMK-BI.

Besar BO nonpersonalia penyelenggaraan SMK-BI lebih besar dari Standar Biaya SMK SSN merupakan kondisi yang tidak perlu dipersoalkan bila dilihat dari adanya empat komponen pengeluaran tambahan, yaitu (1) benchmark kurikulum dan bahan ajar dg OECD, (2) kemitraan dengan industri dan sister school, (3) kegiatan lain, dan (4) pengelolaan. Masalah yang perlu dicari solusinya adalah proporsi dana dari Pemerintah, orang tua peserta didik, dan pihak lain yang berkepentingan.

\section{Penutup}

Berdasarkan penelitian dapat disimpulkan bahwa biaya operasi (BO) nonpersonalia penyelenggaraan SMK-BI/RSBI di DIY adalah sebagai berikut: (a) pengelola belum pernah menghitung besar $\mathrm{BO}$ nonpersonalia per Program Keahlian (PK) karena pengelola sekolah belum tahu bahwa ada Permendiknas No 69 Tahun 2009 tentang Standar Biaya SSN dan anggaran sekolah disusun sesuai dengan arahan Dinas Pendidikan Kabupaten/Kota yang belum mengakomodasi perbedaan kebutuhan BAHP antarPK; (b) rerata besar BO nonpersonalia per satuan pendidikan (bukan per PK) adalah sebesar Rp2.166.237,00 untuk kelompok bidang non-teknik dan sebesar Rp2.287.066,00 untuk kelompok bidang teknik, berarti hampir sama dengan $\mathrm{BO}$ nonpersonalia pada SMK SSN; c) dana untuk BO penyelenggaraan SMK-BI/RSBI dari Pemerintah relatif kecil, yaitu 10\% s.d. 16\% sehingga tidak cukup untuk pengadaan BAHP yang mencapai 10,5\% untuk kelompok non-teknik dan 19,4\% untuk kelompok teknik. Akibatnya, komite sekolah (orang tua siswa) harus menanggung sebagian besar ( $84 \%$ sampai dengan 90\%) BO nonpersonalia, suatu beban yang cukup berat bagi orang dari golongan ekonomi lemah.

Berdasarkan hasil penelitian, dapat disarankan sebagi berikut: (a) pemerintah perlu lebih aktif melakukan sosialisasi Permendiknas No 69 Tahun 2009 tentang Standar Biaya SSN dan menghitung biaya program peningkatan mutu sekolah seperti SMK-BI atau sejenisnya; (b) pemerintah mengalokasikan dana penyelenggaraan program peningkatan mutu sekolah seperti SMKBI sesuai dengan kebutuhan dikuti dengan panduan penerapan anggaran berbasis kinerja untuk meningkatkan akuntabilitas penggunaan dana.

\section{Daftar Pustaka}

Abbas Ghozali (2010). Ekonomi Pendidikan. Jakarta: Lemlit UIN Syarif Hidayatullah.

Achieve, Inc. (2007). Creating a World-Class Education System in Obio. www.achieve. org

Amat Jaedun. (2010). Pencapaian IKKT pada Operasi SMK RSBI di DIY. Jurnal Pendidikan Teknologi dan Kejuruan Vol 19 NO 2 Th 2010.

Badan Penelitian dan Pengembangan Depdiknas. (2007). Pedoman Penjaminan Mutu Sekolab/Madrasah Bertaraf Internasional pada Jenjang Pendidikan Dasar dan Menengah. Jakarta: Depdiknas.

Bray, M. (2002). The Cost and Financing of Education: Trend and Policy Implication. Manila: ADB

Brock, W., Marshall, R., and Tucker, M. (2009). 10 Steps to World-Class Schools. wnw.washingtonpost.com

Daljono. (2011). Akuntansi Biaya. Semarang: Badan Penerbit Universitas Diponegoro.

Chalker, D.M. dan Haynes, R.M. (1995) World-class scholls: new standards for education. Lancaster: Technomic. 
Depdiknas. (2002). Kegiatan belajar mengajar kurikulum berbasis kompetensi. Jakarta: Puskur Balitbang.

Gasskov, V. (2000). Managing Vocational Training Systems. Geneva: ILO.

Hoeckel, K, (2008). Cost and Benfits in Vocational Education ang Training. $\mathrm{Edu} / \mathrm{edpc} / \mathrm{cert}$

Klein, S., Hoachlauder,G., Beltrnena, R., Beal, T. (2000). Funding of Vocational Education in Obio: Results of National Survey of State. Berkeley: MPR Associates

Klein, S. 2001. Financing Vocational Education: A State Policy Maker's Guide. Berkeley: MPR Associates

Law Song Seng. (2007). Vocational Technical Education and Economic Development-The Singapore Experience. https://www.ite. edu.sg.

Lewin, K. And Caillods, F. (2001). Financing Secondary Education in Developing Countries: Strategies for Sustainable Growth. Paris: IIEP.

Lunenberg and Ornstein. (2000). Educational Administrattion. Belmont: Wadsworth.

Nolker, H. 1983. Pendidikan Kejuruan: Pengajaran, Kurikulum, Perencanaan. Jakarta: Gramedia.

Mun C. Tsang. 1997. Cost of Vocational education. International Journal of Manpower. Vol 18, No 1/2, pp. 63-89. University Press.

Peano, S., Vergel de Dios, B., Atchoarena, D., and Mendoza, U. (2008). Invesment in Technical Vocational Education
(TVET) in Philippines. Paris: IIEP UNESCO

Poston, Jr. W.K. 2011. School Budgeting. Thousand Oaks: Sage.

Psacharopoulos, $G$ ang Woodhall, M. (1985). Education for Development: An Analysis for Investment Choices. New York: Oxford University Press.

Rauner, F. And Maclean, R. (Eds). (2008). Hanbook of Tecnical and Vocational Education and Training Research. Bremen: UNESCO.

Shapiro, H. S. and Purpel, D. E. (2003) by American Educational Studies Association. From "Funding Accountability: States,Courts, and Public Responsbility," Educational Studies, Vol. 34, No. 3, pp. 317-336.

State Departments of Education. (2002). Vocational Education. Education.state university.com.

Stewart (2010). Singapore: Innovation in Technical Education. http://www. apec knowledgebank.org

Swiss Agency for Development and Cooperation. (2005). Costing and Pricing of VET Products and Services. Berne: SDC.

Tilak, J.B.G. dalam Keeves, J.P. and Watanabe, R. (2002), Vocational Education and Training in Asia. New Delhi: National Institute of Educational Planning.

Yin Cheong Chen. (1996). School Efectiveness \& School-based Management. London: Falmer Press. 